Nataša Cigoj Krstulović Ljubljana

\section{UVOD V GLASBENO DELO ČITALNIC NA SLOVENSKEM}

Glasbeno delo prvega obdobja čitalnic na Slovenskem, to je med leti 1848 in $1872,{ }^{1}$ na prvi pogled ni privlačna tema, je le "varianta, ki je umetniško in razvojno manj zanimiva", ${ }^{2}$ ali drugače: obdobje, ki je imelo svoja lastna politična (nacionalna), sociološka in temu ustrezna (utilitaristična) estetska merila. Podrobna raziskava obravnavanega obdobja je vendarle smiselna in potrebna vsaj iz dveh razlogov: bolj natančno kot splošna zgodovina slovenske glasbe se bo lahko posvetila prebujenemu valu nacionalnega, ko izvirna tvornost še ni bila sposobna umetniške uresničitve, in drugič, utegne ostreje zarisati mejo dejanskega in relativnega zamudništva.

Glasbo izrazito družabnih prireditev s skromnimi četverospevi, moškimi zbori, samospevi, preprostimi klavirskimi skladbami in trivialnimi orkesterskimi vložki med dejanji kake šaloigre ali burke resda ne moremo (in ne smemo!) primerjati s sočasnimi dosežki "velikih" evropskih narodov. Čeprav je bilo čitalništvo na slovenskih etničnih tleh potisnjeno $v$ zakotje habsburške province, je bilo vpeto $v$ zgodovino evropskega dogajanja in $v$ čas, $k i$ je bil (in je tudi danes!) eksistenčno usoden za nastajajoče "male" narode. Takrat so se sprožila prva nacionalna identifikacijska znamenja, s pečatom romantizirane naivnosti in pobudniškega zanosa. (Pri tem je mišljena duhovna kultura širših slojev, pri nas ljudstva slovenskega etničnega prostora, ki je živelo pod tujerodno oblastjo.) Istovetnost nekega naroda se $v$ kriznih trenutkih odraža in osredotoča v tistem, kar je ustvaril duh, v kulturi. Če tej istovetnosti preti izginitev, se kulturno življenje intenzivira, dokler kultura sama ne postane živa vrednota, okoli katere se ljudje samodejno zbirajo in jo štejejo za temeljno pogonsko moč $v$ osamosvojitvenih sanjah. To pa je čitalniška kultura ( $v$ kateri je imela glasba eno najvidnejših mest) vsekakor bila.

Namen podrobnejše razprave o zgodnjem obdobju čitalnic na Slovenskem je dvoplasten. Na eni strani bo poskušala obogatiti informacijsko vsebino z novimi podatki iz doslej še nepredstavljenih virov, ki so dostopni, pa še ne pregledani $v$ arhivih in knjižnicah po Sloveniji (zapisniki, programi, blagajniške knjige, korespondenca in podobno) in $v$ podrobno pregledanem časopisju tistega časa kot pomožnem viru. $\mathrm{Na}$

\footnotetext{
1 Pričujoči članek je nastal $v$ zvezi z magistrsko nalogo, ki jo pripravljam pod naslovom Glasbeno delo čitalnic na Slovenskem do ustanovitve Glasbene matice (1848-1872) na oddelku za muzikologijo Filozofske fakultete $v$ Ljubljani.

2 Rijavec A., Slovenskost slovenske glasbe, v:Slovenski glasbeni dnevi, zbornik referatov, ur. Primož Kuret in Julijan Strajnar, Ljubljana 1990, 99.
} 
drugi strani bo obravnava gradiva osvetlila spremembe pod podatkovno vrhnjo plastjo zapisovanja s poudarjenim socialnim zgodovinskim izhodiščem. Se pravi, v nasprotju z glasbeno imanentnim zgodovinopisjem, ki glasbo obravnava avtonomno, ter $v$ povezavi $z$ družbenimi in političnimi okoliščinami časa in slovenskih etničnih možnosti oblikovati zgodovinski obris čitalniškega obdobja na Slovenskem ob prepletanju dogodkov, nosilnih osebnosti in procesov. ${ }^{3}$ Motivacija pri tem ni le pragmatična, torej razlaganje pojavov $v$ njihovi stvarni vzročni zvezi, temveč spoznavna, kar pomeni zajeti glasbeno delo čitalnic $v$ "duhu čitalništva". Zgodovinsko in estetsko zanimanje pa kar sama ponujata vprašanje, kako so primarno vplivale zunajglasbene funkcije na glasbeno življenje in delo, kako so se zrcalile $v$ ustvarjalnih rezultatih, kajti vrednost glasbenih del (ne $v$ smislu pozitivne ali negativne estetske vrednostne sodbe) moremo presojati le, če poznamo in upoštevamo vse okoliščine, v katerih so le-ta nastajala, če zaznamo mrežo zgodovinskega, sociološkega in glasbenega razvoja. In končno je treba upoštevati, da je imela glasba na slovenskih tleh že tradicijo od srednjega veka, toda ne nacionalne.

Letnici 1848 in 1872, ki omejujeta izsek iz slovenske glasbene zgodovine, sta vezani na ustanovitev dveh društev, pomembnih za rojstvo avtohtonega slovenskega glasbenega življenja. Slovensko društvo je bilo ustanovljeno slabe tri mesece po marčni revoluciji. Po svojem namenu in ciljih, ki jih je videlo pred seboj, je bilo bolj literarno in širše kultorološko kot politično. ${ }^{4}$ Glasbeni pomen zrcalita izdaja posvetne pesmarice Slovenska gerlica in priljubljene prireditve (besede), na katerih so peli ne samo $v$ slovenskem jeziku, ampak tudi pesmi slovenskih avtorjev. Obdobje pa se sklene z ustanovitvijo Glasbene matice leta 1872, društva, ki je ob Dramatičnem društvu in Orglarski šoli Cecilijinega društva skrbelo za profesionalizacijo slovenskega glasbenega dela ob nemškem v Deželnem gledališču in Filharmonični družbi.

Nastanek Slovenskega društva je tesno povezan z dunajskimi družbenopolitičnimi dogodki leta 1848. Na slovensko ozemlje je marčna revolucija padla kot $v$ nepripravljeno okolje, po vrhu brez voditeljev, kakršne so imeli Madžari, Poljaki ali Čehi. O tedanji politični izobrazbi ne bi mogli govoriti, zato ni bilo mogoče doseči enotnega narodno-političnega programa, ki ga je rodila ideja Zedinjene Slovenije; ta se je vezala za priznanje narodnih pravic $v$ okviru avstroogrske monarhije. $V$ njeni državniški skupnosti naj bi Slovenci in vsak drugi ohranili svoje posebnosti z narodno in kulturno avtonomijo. Slovenske politične zadeve so bile skromne, kakor izpričuje politično ravnanje Slovenskega društva. To se je strnilo v eno samo "osvoboditveno" geslo: Vse za vero, dom, cesarja. Njegovi ustanovitelji ${ }^{5}$ so menili, da je jezik osnovno samoobrambno sredstvo za etnično kulturo in tisti temelj, na katerem se bo polagoma izoblikovala zavest pripadnosti bodočemu slovenskemu narodu.

Take vrste politična svoboda je doletela Slovence ob maloštevilnem meščanstvu. Meščanstvo, kolikor ga je sploh bilo na Slovenskem, je bilo nemškega in italijanskega rodu.Tudi maloštevilno izobraženstvo je imelo $v$ domačem okolju (in jeziku) pretesno duševo obzorje. Večina je nasprotovala slovenskim naporom, mnogi so bili narodno "mlačni" in polni različnih predsodkov, le malo je bilo zavednih Slovencev. Jedro in

30 modernem zgodovinopisju piše Hayden White $v$ članku Problem pripovedi $v$ sodobni teoriji zgodovinopisja, gl. Vsi Tukididovi možje, ur. Oto Luthar, Ljubljana 1990, 95-135.

4 Glej Letopis Slovenskiga družtva na Krajnskim, Ljubljana 1849, 9.

5 Na protokolu seje odbora Slovenskega društva 29. junija 1848 so podpisani: Dr. Bleiweis, Špor, Kunšič, prof. Martinak, dr. Strupi, Hradecki, Kersnik, Cigale, Rab in Bučar. Glej gradivo v Državnem arhivu Slovenije (odslej DAS), AS 585, fsc. 1. 
večina bodočega slovenskega naroda je bila kmetskega stanu, ki je mislil, da le "tisti nekaj velja, ki nemško zna". Pojma nemštvo in izobraženost sta postala sorodna. Položaj slovenščine se je sicer po I. 1848 izboljšal (prevajali so uradni jezik v slovenščino, slovenski jezik je postal učni jezik $v$ gimnaziji), vendar je še vedno, kot pravi Vasilij Melik, prevladoval kult nemščine kot državnega jezika. ${ }^{6}$ Janez Bleiweis ${ }^{7}$ je rešitev videl $v$ množični in zavestni prebuji občutka za pripadnost enotnemu slovenskem narodu (razkosanost na dežele $z$ ločeno upravo je prebivalce slovenskega etničnega ozemlja razcepila $v$ Kranjce, Štajerce, Korošce in Primorce), v "omikanju" predvsem $v$ najširših, ljudskih slojev. Da bi to dosegli, je bilo potrebno poprej storiti še pomemben vmesni korak: jezikovno združiti etnično ozemlje s slovenskim knjižnim jezikom. Kultura naj bi postala temeljna narodnostna vrednota, pa tudi povod za zbiranje ljudi ob pobudniških predavanjih in govorih, ki so jih spremljale deklamacije, petje in igre v slovenskem jeziku na večernih prireditvah, besedah.

Narodna zavest se je netila na besedah Slovenskega društva in med slovensko inteligenco na Dunaju, Gradcu, Celovcu in Trstu, ki je prišla v stik s tamkaj živečimi rodoljubnimi Slovani. Dunajska Slovenija je bila politično društvo, toda prva je poslala ljubljanski Filharmonični družbi predlog, da naj bi se ta ustanova reorganizirala v prvo slovensko glasbeno društvo. ${ }^{8}$ V Gradcu je delovala Graška Slovenija, delovalo je bralno društvo, leta 1851 in 1852 vršile besede, na katerih je sodeloval B. Ipavec, tedaj študent medicine. ${ }^{9} \mathrm{Na}$ Kranjskem je do leta 1853 delovalo Slovensko društvo, tudi $\mathrm{v}$ Novem mestu so že leta 1848 imeli besedo, ${ }^{10} \mathrm{v}$ Idriji gledališko predstavo, ki je verjetno vsebovala tudi kakšno pevsko točko. Na Štajerskem se je kulturno najprej prebudilo Celje, kjer so diletantje pod vodstvom tiskarja Janeza Jeretina uprizarjali gledališke predstave, na katerih je sodelovala tudi godba narodne straže. Na plakatu za slovensko-nemško predstavo je omenjen nastop slovenskega pevskega društva. ${ }^{11}$ Začela so se ustanavljati bralna društva tudi v podeželskih mestih in trgih, ${ }^{12}$ kjer so do tedaj obstajala le nemška bralna društva in kazine kot središča krajevnega družabnega življenja.

Po prvih uspehih je nastal zastoj kulturnih in političnih prizadevanj, ki je trajal nekaj let. $V$ drugi polovici 50 -ih let 'so javno govorili in peli slovenske ob nemških pesmih samo še $v$ Katoliški družbi rokodelskih pomočnikov. ${ }^{13}$ Tu in tam so peli kakšno slovensko pesem še v gledališču med nemško igro (1854), ${ }^{14}$ leta 1855 v dvorani

6 Melik V., Problemi in dosežki slovenskega narodnega boja $v$ šestdesetih in sedemdesetih letih, Obdobje realizma v slovenskem jeziku, književnosti in kulturi, ur. Boris Paternu, Ljubljana 1982, 474.

7 Delovanje Janeza Bleiweisa kot osrednje avtoritete takratnega političnega in kulturnega življenja ter urednika Novic zanima raziskovalce tudi v novejšem času, o čemer priča simpozij Slovenske matice leta 1981 in priložnostna razstava, ki je bila letos na ogled v prostorih Gorenjskega muzeja v Kranju.

8 Apih J., Slovenci in 1848. leto, Ljubljana 1888, 119 in Keesbacher F., Die philharmonische Gesellschaft in Laibach, Ljubljana 1862, 93 in 94.

9 Poročilo s programom in potekom teh prireditev glej v članku Frana llešiča: Prvi dve besedi v Gradcu, ČZN, Maribor 1936, 1-21.

$10 \mathrm{Na}$ besedi, ki je bila 19.7.1848 v novomeški kazini, so peli Mornarja (verjetno Flajšmanovega), Popotnika, ilirsko Napred in Dolensko (verjetno Potočnikovo). Glej Sloveniens Blatt,1848, 6, 24.

$11 \mathrm{O}$ tem društvu nisem našla drugih podatkov. Omenjen plakat za predstavo leta 1851 je shranjen $v$ domoznanskem oddelku Osrednje knjižnice v Celju.

12 Glej Prijatelj I., Slovenska kulturnopolitična in slovstvena zgodovina 1848/1895, I.zv., Ljubljana 1955.

13 Cesarsko kraljevo deželno glavarstvo je dovolilo delovanje društva aprila leta 1855. Na začetku je bilo 78 rednih članov, ki so se zbirali ob nedeljah ter se med drugim učili tudi petja, zvečer pa so se razveseljevali ob petju, deklamacijah in igri. Njihove večernice omenjajo Novice še v šestdesetih letih. Viktor Steska omenja Alfreda Khoma kot njihovega pevovodjo. Glej Zgodnja Danica 1855, 42, 177 in 178 ter Steska V., Javna glasbena šola v Ljubljani, v: Cerkveni glasbenik 4/1929, št. 11, 12, 179 in 180. 
goriške kazine,$^{15}$ leto pozneje so peli slovenske pesmi $v$ čolnih na Ljubljanici. ${ }^{16}$ Leta 1857 so peli v reduti venec slovenskih pesmi pod vodstvom Antona Nedvěda, ${ }^{17}$ kar je že naznanilo skorajšnji konec kulturnega mrtvila. Na svečnico naslednjega leta so ob priliki proslave Vodnikovega rojstva priredili narodno slavnost, slovesno besedo pod Nedvědovim vodstvom, ki je privabila vse narodno misleče in tudi precej kranjskih Nemcev.

Po razglasitvi oktobrske diplome leta 1860 so dežele dobile večjo avtonomijo in sprostilo se je društveno in politično delovanje. Družabno, narodno in politično življenje Slovencev se je razširilo iz Kranjske tudi v druge dežele. (Štajerski Slovenci so bili konec šestdestih politično najaktivnejši, sprožili so tabore, v Mariboru pa je začel izhajati tudi Slovenski narod.) Zaživele so mnoge čitalnice, ki so se hitro množile tudi $\checkmark$ manjša mesta in trge, celo na podeželje. ${ }^{18}$ To je bila takrat edina avtohtona oblika javnega nastopanja, ki bi težko pridobivala množice brez izvirne slovenske pesmi. Domači ustvarjalci so dobili priložnost in spodbudo, za njo so bili motivirani vsi slovenski glasbeniki tistega časa. Prva čitalnica te dobe, ne toliko bralnica knjig ali časnikov, marveč "dom narodne zavesti", se je ustanovila v začetku leta $1861 \mathrm{v}$ Trstu. Bila je namenjena vsem tržaškim Slovanom, zato je bil spored njenih prireditev slovansko obarvan. Pod vodstvom Jana Lega so peli srbske, češke in slovenske pesmi. Tudi naslednja, Slovanska čitalnica v Mariboru, je na soroden način širila narodno zavest ob tam službujočih Čehih. ${ }^{19}$ Janez Miklošič je vodil petje in priložnostno kaj zložil. Z njo in kasneje celjsko sta bila tesno povezana Gustav in Benjamin Ipavec. V celjski čitalnici je skrbel za petje Gregor Tribnik, ki je na besedah tudi večkrat improviziral na klavirju ter za njene potrebe zbral obstoječe Slovenske pesmi za četvere moške glasove in dodal nekaj svojih. Ljubljanska Narodna čitalnica, oziroma "Bleiweisova čitalnica" je imela prvo leto Nedvěda, poklicnega glasbenika, ki je vodil čitalniški pevski zbor in skladal zbore na slovenska besedila. Kasneje sta zbor prevzela Vojteh Valenta in Jožef Fabjani, priložnostno sta tudi kaj napisala. Spored čitalnic $v$ deželi Kranjski je bil ilirsko-slovensko obarvan. Ilirizem je odmeval v budnicah in davorijah, ${ }^{20}$ ki jih Slovenci v začetku nismo imeli. Družabne in politične spremembe so spodbujale tudi petje $v$ telovadnem društvu Južni Sokol (1863-1867). ${ }^{21}$ Pevski zbor (nekateri člani so bili isti kot $v$ čitalniškem) je vodil Vojteh Valenta, ki je bil tudi pogosto v pripravljalnem odboru za sobotne sokolske večernice. Z ustanovitvijo čitalnice v Bistrici na Notranjskem je bil neposredno povezan Fran Gerbič, ki je tam učiteljeval do odhoda na študij v Prago. Na sporedu njene prve besede avgusta 1864 so kar štiri njegove pesmi. Čitalnica je po njegovem odhodu $v$ Prago pešala, le ob poletnih počitnicah je poživil njeno delovanje, kot avgusta naslednje leto $s$ petjem in $z$ dvema

14 Novice (odslej samo N) 1854, 8, 32.

15 N $1855,21,87$.

$16 \mathrm{~N} 1856,376$ in 372.

$17 \mathrm{~N} \mathrm{1857,29,112.}$

18 Do ustanovitve Dramatičnega društva 1867 so zaživele naslednje čitalnice: 1861 v Trstu, Ljubljani in Mariboru, 1862 v Celju in Tolminu, 1863 v Gorici, Škofji Loki, Ptuju, Kranju in Celovcu, 1864 v Ajdovščini, Ilirski Bistrici, Vipavi in Planini, 1865 v Metliki, Novem mestu in Sevnici na Štajerskem, 1866 v Šentvidu nad Ljubljano in Idriji, $1867 \vee$ Jelšanah in Solkanu. Letopis Slovenske matice za leto 1869 omenja kar 57 čitalnic: 16 na Kranjskem, 16 na Goriškem, 8 na Tržaškem, 13 na Štajerskem, 2 v Istri in 2 na Koroškem.

19 Glej izvirno gradivo v rokopisnem oddelku Univerzitetne knjižnice v Mariboru, Ms 201.

20 Davorije so imenovali Hrvati politično aktualne množične pesmi rodoljubnega značaja, budnice.

21 Gradivo omenjenega društva hrani DAS, Arhiv ljubljanskega Sokola, škatla 2. 
novima moškima zboroma. ${ }^{22}$ Čitalnice ob mejah slovenskega etničnega prostora so imele poseben položaj. Zlasti primorske so bile "med kladivom in nakovalom" in čeprav (ali temu navkljub) so jih ogrožali Nemci in Italijani, so se širile zlasti po vaseh. $\mathrm{Na}$ Primorskem ( $v$ sedanjih mejah) je bilo leta 1869 skoraj tri petine vseh slovenskih čitalnic. ${ }^{23} \mathrm{~S}$ kanalsko čitalnico sta bila povezana rojaka Josip Kocjančič, najprej še kot dijak, ko je to čitalnico ustanovil leta 1867, v osemdesetih pa aktivno sodeloval na njenih besedah in zanje harmoniziral ljudske napeve ${ }^{24}$ ter Avgust Leban, ki ji je posvetil Kanalsko. Goriško čitalnico je najprej vodil pevovodja in skladatelj Anton Hribar.

Petje je bilo del prireditev $v$ čitalnicah, ki so obsegale še govore, predavanja, deklamacije, igre in ples, vendar najbolj privlačna točka sporeda. Zanimivo je, da je ponekod pevski zbor obstajal celo pred ustanovitvijo čitalnice, kot v Kamniku, kjer so že tri leta prej ustanovili pevsko društvo. ${ }^{25}$ Število rednih čitalniških pevcev je bilo različno in spreminjajoče se; od kvarteta, kot $v$ Tolminu, ${ }^{26}$ do 12 in več pevcev. Pevovodje so bili največkrat učitelji in organisti, morali so se prilagajati glasbenim sposobnostim pevcev, ki so jih imeli pred seboj. Na vztrajno prihajanje k vajam so vplivale še druge okoliščine.$^{27}$ Čitalnice, ki niso imele dovolj pevskih moči (ptujska), pa so raje prirejale gledališke predstave. ${ }^{28}$ Glasbeni del prireditev so ponekod (v večjih mestih) popestrili nastopi vojaške godbe, začasni diletantski orkester ( $v$ Ljubljani ust. I.1863, Kamniku ust.I. 1869 in Kranju ust. I. 1870) ali "salonsko" preludiranje na klavirju. Prvo komorno točko omenjajo Novice šele leta 1864, ko so v Ljubljani godli Pregel, Kos in Bučar, $v$ Gorici pa je istega leta igral instrumentalni kvintet. ${ }^{29}$ Idejo komornega muziciranja so najbrž dobili pri Filharmonični družbi, ki je prirejala samostojne komorne večere že leta $1861 .{ }^{30}$

Prvo desetletje čitalniškega gibanja se zdi z današnje perspektive kot zametek poznejšega kulturnega in glasbenega pomena. Po letu 1867 so Slovence združevali in povezovali tabori, po mnenju Vasilija Melika "ena najsvetlejših točk $v$ zgodovini Slovencev pred prvo vojno" ${ }^{11}$ in množična manifestacija za program Zedinjene Slovenije. V ospredju so bila politična vprašanja, ki so pripeljala do strankarskih nasprotij med liberalno in klerikalno mislečimi. Glasbeno delo je tedaj prišlo do boljših razvojnih možnosti. Dramatično društvo je uresničilo zamisel Leopolda Kordeša iz leta 1848 o slovenskem gledališču. Čitalniške glasbene ambicije so se začele razraščati, dober zgled pa so imele v nemškem gledališču oz. v Filharmonični družbi. Glasbena prizadevanja so vse bolj in bolj prehajala $v$ roke poklicnih slovenskih glasbenikov. Potreba po profesionalizaciji slovenskega glasbenega dela je slednjič dozorela z ustanovitvijo Glasbene matice 1872. leta v Ljubljani, drugod pa samostojnih pevskih zborov, ki so nadaljevali glasbeni del čitalniške dejavnosti.

$22 \mathrm{~N} \mathrm{1864,} \mathrm{31,} 254$ in N 1865, 36, 266.

23 Marušič B., Čitalniško gibanje na Primorskem in nastanek narodne čitalnice v Rihemberku, v: Ob stoletnici rihemberške čitalnice, Branik 1968, 5.

24 Bevdaž K., 100 let kanalske čitalnice, Kanal 1967, 7-8.

25 Torkar Z., Narodna čitalnica v Kamniku, Kamnik 1991, 21. in N 1866, 6, 50.

26 Oblak F., Dr. Karel Lavrič in njegova doba, Gorica 1906, 3.

27 Težave zaradi nerednega prihajanja k vajam so imeli v Celju. Glej zapisnike Celjske čitalnice v Zgodovinskem arhivu $v$ Celju.

28 Gradivo ptujske čitalnice hrani Zgodovinski arhiv v Ptuju.

29 N 1864, 15, 124 in N 1864, 23, 188.

30 Godalni kvartet so sestavljali Nedved, Zappe sen., Zappe jun. in Urban. Glej Laibacher Zeitung 1861, 274, 968.

31 Melik V., ib., 472. 
$V$ petdesetih in šestdestih letih 19. stoletja so živeli Nemci in Slovenci v glasbenih in drugih oblikah kulturnega delovanja tolerantno in brez očitnih nacionalnih nasprotij. Slovensko društvo je svoje besede izvajalo s pomočjo Filharmonične družbe in kapelnika Stanovskega gledališča Gašparja Maška. ${ }^{32}$ Slednja je zadržala privilegij uradne koncertne ustanove, kamor so zahajali tudi umetnosti željni slovenski rodoljubi. Nemci so bili v prvih letih člani čitalnic, obiskovali so njene prireditve in sodelovali na njih. Filharmonična družba je pomagala ljubljanski čitalnici pri večjih besedah. Šele kasneje so se nacionalna nasprotja prelevila $v$ ponemčevalni pritisk, zato je prejšnje sožitje prešlo $v$ tekmovalnost in polariziranje nemškega in slovenskega glasbenega življenja: koncertno okrog Filharmonične družbe nasproti Glasbeni matici, glasbenogledališko delo okrog Deželnega gledališča nasproti Dramatičnemu društvu.

Pri pregledu izvorov, osnov in začetkov slovenskega čitalništva v glasbi se je treba ustaviti ob idejnih zgledih, ki so prišli iz Češke in Hrvaške, kjer je bil pobudnik čitalnic grof Drašković. Fran Gerbič je zapisal leta 1911 ob 50-letnici pevskega društva Hlahol, da je bilo le-to ustanovljeno približno ob istem času kot čitalnica in: "koj iz početka nekako zvezda vodnica, ki nam je kazala pot". ${ }^{33} \mathrm{Na}$ teh besedah je panslovanska ideja enakopravnosti kulturno združevala narode. Nemci čitalnic niso poznali, pač pa so na začetku 19. stoletja $v$ času politične depresije pod Napoleonovo oblastjo odmevali ideali francoske revolucije, svobode in enakosti. Spodbudili so fenomen moških pevskih družb oz. liedertaflov. Družba mož se je zbirala ob določenih večerih in za zabavo so prakticirali štiriglasno petje brez spremljave. Vodila jih ni samo želja po družabnem petju, marveč sočasni val nemškega nacionalizma. Na južnonemškem prostoru so se jim pridružila še pedagoška prizadevanja $s$ težnjo širšega ljudskega muziciranja. ${ }^{34}$ Pevska društva so nastajala povsod, tudi v majhnih mestih, društva pa so se med seboj srečevala na pevskih slavjih. $V$ habsburški monarhiji je bil po tem vzoru ustanovljen Männergesangs Verein na Dunaju šele leta 1843, v Mariboru leta $1846 .{ }^{35}$ $\mathrm{Na}$ pobudo graškega pevskega društva je bila leta 1862 v Mariboru nemška pevska manifestacija pevcev iz Celja, Maribora, Ptuja, Ljubljane, Radgone in Celovca. Pevski shod $v$ Tržiču je organiziral tamkajšnji Liedertafel (ustanovljen 1848) ${ }^{36}$ leta 1862, omenja ga tudi kronist mesta Tržič, Viktor Kragl. Sprva je gojil slovensko (tudi kakšno Tomaževčevo so zapeli) ${ }^{37}$ in nemško petje, kasneje pa le še nemško, obžaluje poročevalec ob njegovem pevskem obisku $v$ Kranju. ${ }^{38}$ Prvo samostojno slovensko pevsko društvo naj bi nastalo v Krškem, duša tega zbora pa je bil Dragotin Ripšl. ${ }^{39}$ Slovenski pevski tabori so se začeli nekaj desetletij za nemškimi, 1884 na Ptuju. Zdi

32 Glej Računske priloge Slovenskega društva 1849, 1850, 1851 in 1852 v arhivu SD v DAS, AS 585, fsc.2, kjer je večkrat navedeno plačilo Gašparju Mašku.

33 Novi akordi, 1911, 4, 49-51.

34 Dietl H., Beiträge zur frühgeschichte des Männergesange, Würzburg 1938.

35 Ustanovil ga je učitelj Anton Tremmel, ki je leta 1825 ustanovil tudi tamkajšnji Musikverein, petje je vodil Karl Martini.Več o njem glej v Rappold K., Die Entwicklung des Männerchorwesens in Steirmark, Graz 1962.

36 Liedertafel je že leta 1848 ustanovil tedanji oskrbnik tržiške graščine Janez Pogačnik, ki je bil tudi njen prvi pevovodja. Priložnostno je komponiral, slovel je njegov Te deum. Glej Kragl V., Zgodovinski drobci župnije Tržič, izd. Župni urad v Tržiču 1936, 53 in 402.

37 Verjetno je njihov rojak Tomaževec (Josef Tomashoviz) te skladbe priložnostno zanj napisal. Po študiju v Gradcu pa se je posvetil glasbi in petju $v$ Celovcu, kjer je vodil moški pevski zbor in pisal nemške pesmi.

38 Poročilo navaja, da so oktobra 1848 Tržičani v Kranju peli tudi Potočnikovo Zvonikarjevo, Tomaževčevi Bratje Slovenci smo in Bleško jezero ter Padovčevo Moje jutro. Glej Illirisches Blatt (poslej IB) 1848, 89, 256, IB 1848, 90, 360 in IB 1849, 70, 279 in 280.

39 N 1871, 52, 421 in Druzović H., Katero je bilo prvo slovensko pevsko društvo, Zbori; 1935, 5, 28. 
se, da je bila slovanska različica moškega petja nekaka protiutež nemškemu petju, tako kot so bile slovanske nacionalne šole protiutež prevladi germanske glasbe, kar je razvidno tudi s sporedov. Pri prvih so bile na sporedih pesmi slovanskih (pri nas tudi slovenskih) ustvarjalcev, pri drugih pa le nemških, kot na primer na sporedu celjskega nemškega pevskega društva. ${ }^{40}$

Med neposrednimi vzroki za nastanek čitalniškega petja pri nas je $v$ ospredju ideja o preprostih, dopadljivih pesmih na narodnoprebudno besedilo. Ljudje so si pesmi zapomnili in besedilo, tolikokrat peto, je doseglo namen. Vzbudilo je ljubezen do slovenske dežele in zavest o pripadnosti slovenskemu narodu.

Drugi, nič manj pomemben in posledični vzrok, je bilo oživljanje slovenske ljudske dediščine oz. pesmi v "ljudskem duhu". Že v času narodnega preporoda piše Žiga Zois Valentinu Vodniku ob pesmi Zadovoljni Kranjc (Vodnikovo besedilo ima v prvem zvezku Slovenske gerlice podložen stari kranjski napev), da morajo biti njegove pesmi $v$ ljudskem duhu in za ljudstvo, pri čemer naj ne gre za posnemanje ljudskih pesmi, ampak za vedri ton ljudskih poskočnic. ${ }^{41}$ Takšne preproste pesmi so bile potrebne za kulturno "omikanje" širokih množic tudi v obdobju čitalnic, približale so umetnost vsem slojem, ker so bile blizu njihovem čustvovanju, lahke za izvedbo in so jih vsi lahko peli.

Neposredne glasbene osnove za začetek čitalniškega petja dandanes vidimo ob cerkvenih in posvetnih pesmih ustvarjalcev Gregorja Riharja in njegovega kroga. Rihar je bil prvi skladatelj, ki je s prirojenim melodičnim talentom zadel splošno slovensko občutje lepega $v$ glasbi. Njegove preproste pesmi so bile blizu ljudskim, med cerkvenimi in posvetnimi pa ni bilo bistvene razlike. $V$ tem mu je najbolj dosledno sledil Blaž Potočnik. Njune pesmi so peli na besedah Slovenskega društva, v 50-ih letih na Dunaju in v Gradcu, najdemo jih tudi na sporedih čitalnic v 60-ih in 70-ih letih. Natisnjene so bile $v$ Slovenski gerlici (njen tretji zvezek je uredil Rihar), nekatere so ponarodele. Z Zvonikarjevo Blaža Potočnika so pozdravili prihod cesarja v Mariboru 1856. leta. ${ }^{42}$ Njune pesmi so torej živele $v$ narodu, tako kot sta onadva za narod. Blaž Potočnik je bil med odborniki Slovenskega društva, skrbel je tudi za slovenski jezik (izdal je slovensko slovnico $v$ nemškem jeziku). Leta 1866 je ustanovil še čitalnico $v$ Šentvidu nad Ljubljano, ki ji je ostal zvest do smrti.

Njuna mlajša sodobnika sta bila Jurij Flajšman in Miroslav Vilhar. Prvi je vodil pevski del prireditev Slovenskega društva. Zapisnik, datiran z 11. majem 1849 omenja tudi "šolo slovenskega petja", v kateri naj bi bil učil. Vilhar je zložil Jamsko Ivanko, prvo slovensko spevoigro in jo posvetil "slavnemu" Slovenskemu društvu; podaril mu je 500 izvodov, ki jih je bil natisnil na lastne stroške. ${ }^{43}$ Ustvarjalce prvega čitalniškega kroga Flajšmana (roj. 1818), Vilharja (roj. 1818) in delno Kamila Maška (roj. 1830) na zunaj družita pripadnost isti generaciji ter narodno pobudniška ideologija. Poklicni glasbenik je bil le Kamilo Mašek, glasbeno se je izpopolnjeval na Dunaju in se v Ljubljano vrnil leta 1854. Vsi so pisali "uporabno glasbo", za množično petje. Takšno, kakršne si je želel Bleiweis, takratni "oče slovenskega naroda": za zabavo in kratek čas ter z ideološko usmerjenim ciljem. Pri pisanju jih je vodila predvsem ideja splošnega

40 Zanimivo je pregledati spored večera graškega in celjskega nemškega pevskega društva v Celju dne 4 . junija 1865. Peli so Marschnerja, Esserja, Abta, Otta, Dürnerja, Rückena, Schuberta in Wagnerja. Programe hrani oddelek za posebne zbirke, raziskovalno delo in dokumentacijo v Osrednji knjižnjici Celje.

41 Koruza J., Vodnikov Zadovolne Krajnc, v: Slovstvene študije, ur. Jože Pogačnik, Ljubljana 1991, 309-318. 42 N 1856, 301.

43 Glej zapisnik Slovenskega društva 8 . marca 1850 v DAS. 
narodnostnega ozaveščanja. Sproščala se je z močjo njihove resnične nadarjenosti za glasbo. Zavestno so se prilagodili izvajalskim možnostim in "slušnim" pričakovanjem poslušalcev. Občinstvo ni bilo zahtevno, zato so bile preproste in dopadljive stereotipne pesmi največ, kar jim je šlo $v$ uho. Glasbena izobrazba za tako muziciranje ni bila potrebna, tudi posebne pevske izkušnje ne. Med ustvarjalci, izvajalci in poslušalci je tekla vzajemna čustvena komunikacija: ugodje - veselje - stopnjevana čustvenost navdušenje - spoznanje - razumevanje - vtis soudeleženosti - zanimanje za nove pesmi - spodbuda za ustvarjanje. Potrebe so torej sprožale nastajanje novih pesmi, toda izvirnost je največkrat zamenjevala rutina, naslonjena na priznan vzorec, ki je zagotavljala Flajšmanu neizmerno priljubljenost. Manj je znano, da je zaprosil (in tudi dobil) denarno nagrado "zaslužnim avstrijskim skladateljem". ${ }^{44}$

Nastalo je relativno veliko podobnih skladb, nobeni ni botrovala stroga kritiška lupa. Estetska presoja je slonela na čutnem in ne spoznavnem vtisu. Novice so bile polne hvale za vsakogar, ki je ustvarjal v slovenskem jeziku. Bleiweis je imel Flajšmana za zgled rodoljubnega ustvarjalca. Ob izidu prvega zvezka Slovenske gerlice 1848 ga je hvalil tudi Leopold Kordeš v Illirisches Blatt. ${ }^{45}$ Nasploh so Novice hvalile vse in vsakogar v superlativih. Zanimivo je, da so kritizirale le malo naprednejšega Josipa Tomaževca (Slovensko društvo tudi ni sprejelo njegove ponudbe, da bi zanj pisal nove slovenske pesmi), ${ }^{46}$ ker so njegove pesmi odstopale od slušnih stereotipov. To pretirano samoljublje je bilo na začetku upravičeno, a je bilo kasneje krivo zastoja v razvoju čitalniških prireditev. Kriterij vrednotenja jim je bila kratkost pesmi, relativna hitrost in glasnost. ${ }^{47}$ Strofična oblika, silabična melodija v zgornjem glasu, enostavna harmonija v T-D območju dura in jasen ritem, vezan na besedo. Besedila idealizirajo slovensko deželo, naravo in prijateljstvo. Estetski rezultat je bil skromen, vendar povzdignjen nad raven ljudskega godčevstva Matije Kračmana ${ }^{48}$ ali pesmi iz Ahacljeve in Hašnikove zapuščine.

Slabih deset let kasneje, na začetku 60 -ih let 19. stoletja se je začela oglašati druga skupina ustvarjalcev, lahko bi ji skoraj rekli druga generacija, ne toliko zaradi letnic rojstva - Anton Nedvěd (1829), Gustav Ipavec (1831), Davorin Jenko (1835) in Anton Hajdrih (1842), kot zaradi vsebinskih in izraznih novosti. Slednjima sta bila Rihar in Kamilo Mašek učitelja. Docela ali vsaj deloma so se izvili iz spon diletantizma. Bili so ambicioznejši, estetsko in glasbeno bolj razgledani kot Vilhar ali Flajšman, saj so imeli zglede $v$ glasbeno razvitejših mestih, kjer so bivali med študijem. Nedvěd in Hajdrih sta jih prinesla iz Prage, Jenko z Dunaja, G. Ipavec iz Gradca. Njihove pesmi so prepevali na besedah povsod po Sloveniji, bolj ali manj so tudi osebno sodelovali $s$ čitalnicami. Nedvěd zlasti prvo leto, ko je vodil čitalniški pevski zbor. Jenko zaradi bivanja na tujem ni imel $z$ domovino pogostih stikov. Obiskal pa je njemu in njegovim pesmim posvečene besede oktobra 1863 v Križankah v Ljubljani in decembra $1869 \mathrm{v}$ ljubljanski čitalnici. ${ }^{49}$ Tudi Hajdrih se je zaradi študija v Pragi in službe v Trstu le priložnostno udeleževal čitalniškega življenja. Še kot konservatorist je z Gerbičem pel na večernici Južnega Sokola $v$ Ljubljani leta 1866. Kasneje, ko se je zaradi službe

$44 \mathrm{~N} 1866,6,51$

45 IB 1848, 83, 332.

46 Glej zapisnik št. XXXV 1. rožnicveta 1849 Slovenskega društva v DAS.

$47 \mathrm{Na}$ to kaže tudi pregled pesmi v Slovenski gerlici.

48 Steska V., Šmarski šomaster Kračman Matej, Pevec 14/1933, 3-6, 13-15 in Steska V., Kančnik Andrejnarodni pevec, Pevec 13/1933/34, 25-27, 34-38.

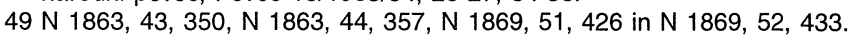


preselil iz Trsta, je organiziral pevski kvartet, $s$ katerim je prebujal pevsko veselje $v$ odročnejših primorskih krajih. Najtesneje je bil s čitalnicami (predvsem štajerskimi) povezan Gustav Ipavec. Kot član celjske čitalnice je pel v šentjurskem kvartetu (brata Ipavca in Ripšla) na njenih besedah in pošiljal svoje pesmi Slovanski čitalnici v Maribor. ${ }^{50}$ Zložil je tudi himno ljubljanskemu Južnemu Sokolu (besedilo pesmi z naslovom Sokolska je napisal Davorin Terstenjak), za kar so ga izvolili za častnega člana. $^{51}$

Sopotnik drugega čitalniškega kroga je bil Benjamin Ipavec, pevovodja na slovanskih besedah $v$ Gradcu leta 1851 in 1852, pa tudi še $v$ šestdesetih in sedemdestih letih. $^{52}$ Čeprav je deloval na obrobju čitalniškega dogajanja na Slovenskem, najdemo njegove pesmi skoraj na vsakem sporedu besed. Ob otvoritvi kranjske čitalnice je na Levstikove besede priložnostno zložil pesem Ob Prešernovem grobu. Na razpis Novic za najboljši napev k pesmi Bleiweisovega malika Koseskega "Kdo je mar?"53 je poslal svojo uglasbitev. Nagrado je dobil Gašpar Mašek, Ipavčevo delo pa se je uvrstilo $v$ čitalniške sporede. $V$ Zagrebu ga je tamkajšnje pevsko društvo Kolo za to pesem nagradilo $s$ častnim članstvom. Prizadeval si je tudi za pravo slovensko nacionalno opero in njegova spevoigra Tičnik (1866), večkrat uprizorjena na čitalniških besedah, je pomembna stopnica $v$ razvoju do nje.

Ustvarjalci drugega čitalniškega kroga so bili še vedno povezani (in odvisni) od aktualne stvarnosti, kulture in načina življenja. Rodoljublje, ki je rodilo Koseskega in Tomana, je doseglo svoj vrhunec v Napreju Simona Jenka, pesmi, ki je postala $v$ uglasbitvi Davorina Jenka slovenska himna in so jo navdušeno prepevali tudi zunaj slovenskega prostora. V nasprotju s Simonom Jenkom je Levstik nadaljeval "prešernovski" tip nepatetičnega kulturnega slovanstva in želel preseči domoljubno kovanje rim. Navzkrižje med staroslovenci in mladoslovenci je odmevalo tudi v kulturi področju, Levstik kritično nastopi proti Bleiweisovem načelu preproste, koristne "umetnosti". Tako kot med pesniki, se je tudi med skladatelji kazal individualni ustvarjalni premik. Še vedno so nastajale prave slovenske budnice (npr. Budnica G. Ipavca), napitnice in društvene himne (npr. Miklošičeva in B. Ipavčeva Mar-i-bor na Tomanovo besedilo), $v$ katerih je veljalo načelo, da naj besedila postanejo znana $s$ pomočjo glasbe, družabno vabljive pesmi v plesnem ritmu in efektne pesmi za bariton ali tenor z brenčečim zborom. Nekatere ustvarjalce, ki so bili tudi sami pevci, je vodil notranji glasbeni nagib. Glasbe niso načeloma podrejali besedilu, temveč so z glasbenim jezikom poskušali doseči željeni učinek. Okus poslušalcev, ki je prej zahteval preizkušeno popularno pesem, se je postopoma spreminjal. Skladatelji niso več pisali po modelu, ampak skladbe, ki so imele izvirno (čeprav še vedno vabljivo) melodijo in celovitejšo obliko, podobno "glasbeni umetnini".

Čeprav štejemo slovensko glasbeno kulturo tega časa $v$ skrajno obrobje srednjeevropske glasbene zgodovine 19. stoletja, zrcali naš prehod $v$ zgodnji "romantizem", ki sicer ni tako reprezentativen kot npr. nemški. Njegova posebnost se

50 Ohranjeno je pismo Gustava Ipavca mariborski čitalnici leta 1862, v katerem omenja, da mu prilaga Potpourri, Potoček in Lahko noč. Glej gradivo Slovanske čitalnice v domoznanskem oddelku Univerzitetne knjižnice v Mariboru, Ms 201, mapa 3, ovoj 20.

51 Glej zapisnik Južnega Sokola, gradivo v DAS, arhiv ljubljanskega Sokola, škatla 2.

$52 \mathrm{~V}$ rokopisnem oddelku $v$ NUK se je po naključju našlo vabilo na slovansko besedo leta 1876 , kjer je kot pevovodja omenjen B. Ipavec.

53 Zanimivo je, da so $v$ razpisu navedena podrobna navodila za oblikovanje napeva, ki je moral biti $v$ narodnem duhu in kolikor mogoče lahek za petje. Glej N 1862, 20, 155. 
kaže $v$ redukciji in retardaciji posameznih oblik in stilni nedorečenosti oz. kot piše Borut Loparnik, "skoraj-stilu". ${ }^{54}$ Odmaknjeni in zaprti smo se zadovoljili s preprostimi samospevi, četverospevi, sprva le moškimi in kasneje tudi mešanimi zbori, spevoigrama Jamsko Ivanko in Tičnikom, skromno kantato Kdo je mar?. V času, ko so drugje že imeli nacionalno opero smo mi nanjo čakali do konca stoletja, na simfonično in operno glasbo pa še dlje. Bolj smiselna je primerjava (ne $v$ ugotavljanju podobnosti, pač pa razlik) tistega segmenta glasbenega življenja, na katerega so vplivali zunajglasbeni dejavniki in se je tako kot pri nas zgoščeval v vokalni glasbi, predvsem zborih. Carl Dahlhaus liedertaflovstvo vrednoti kot drugo ali celo tretjerazredno glasbeno kulturo in ji prida značaj trivialnega, ${ }^{55}$ Jiri Fukač smatra zbirko Venec, ki je izšla $\vee$ Pragi 1835, in vsebuje takrat popularne narodnoprebudne češke zbore, za zastoj ali celo nazadovanje $v$ razvoju glasbenega življenja. ${ }^{56}$ Pozitivna ali negativna vrednostna sodba pa se $v$ naši takratni glasbeni situaciji ne more opreti na poprejšnjo nacionalno dediščino. Glede na danosti zgodovinskega trenutka $v$ času in prostoru, na opisane možnosti in zmožnosti, bi veljalo gledati na situacijo pri nas $v$ povsem realni luči. To je čas, ko se je umetna posvetna glasba počasi luščila iz t.i. "popularne glasbe", zbrane $v$ idealiziranih zbirkah pesmi $v$ "ljudskem duhu", čas dovolj izvirnih četverospevov ter umetniško povprečnih utilitarističnih zborov in samospevov. Presojo je treba naravnati $v$ ožje okvire, znotraj obstoječega. Pri funkcionalni glasbi je, kot pravi Hans Heinrich Eggebrecht, "smiselno presojati odnos med glasbo in smotri, katerim služi". ${ }^{57}$ Podobno je za slogovnimi spremembami zaostajala tudi slovenska književnost, ki se je najprej urila $v$ liriki in $z$ njo postavljala temelje kasnejšemu pripovedništvu (romanu) in drami. Čeprav, meni Dragotin Cvetko, slovenske glasbe za leto 1848 ne moremo "ne z vidika kvalitete ne stilno ugodno oceniti" ${ }^{58}$ in smo s kompozicijsko-tehničnega vidika zaostajali še nekaj desetletij, pa so $v$ provinco vendarle počasi prodirali aktualni tuji idejni zgledi.

V soglasju z evropskimi prizadevanji smo imeli individualno regionalno glasbeno kulturo: ideja "služiti narodu", se je ravnala po realnem stanju, saj je slovenski narod takrat šele začel nastajati. "Romantični" duh je bil bolj imperativ zavezanosti narodu, njegovim kulturnim in družbenim potrebam. Takšne so bile tudi besede na naših tleh.

Čitalnice so bile preproste v svojih sredstvih, a uspešne v učinkih, ker so bile izraz svoje dobe, utemeljene $v$ tedanjih razmerah. Rodile so sad zato, ker je bil pristen vrelec domačega duha in nesporne nadarjenosti za glasbo. Za slovenske razmere je bilo to obdobje petindvajsetih let izredno pomembno. Izoblikovalo je temelje procesu postopnega izoblikovanja avtohtone, slovenske glasbe, zastavilo prehod iz diletantizma v profesionalnost, od skrajno preproste spevoigre Vilharjeve Jamske Ivanke, do opereti podobnega Ipavčevega Tičnika. Torej govorimo o njem z radovednostjo in dvomom, toda brez zamere.

54 Loparnik B., Slovenska glasba in slovenska cerkev v 19. stoletju, v:Vloga cerkve v slovenskem kulturnem razvoju 19. stoletja, ur.France M. Dolinar, Joža Mahnič in Peter Vodopivec, Ljubljana1989, 173.

55 Dahlhaus C., Trivialmusik, v: Die Musik der19.Jahrhunderts /Neues Handbuch der Musikwissenschaft, zv.6, Laaber 1989, 13 in Dahlhaus C., Über die Musikgeschichtliche Bedeutung der Revolution von 1848, v: Melos/Neue Zeitschrift für Musik, 1/1978, 15-19.

56 Fukač J., Der Vokaltyp der tchechischen Wiedergeburt, Colloquium Musik und Wort, Brno 1973, 95.

57 Eggebrecht H. H., Dobra in slaba glasba, v: Dahlhaus C. in Eggebrecht H.H.: Kaj je glasba?, Ljubljana 1991, 55.

58 Cvetko D., Značilnosti in rezultati slovenskega glasbenega dela v letu 1848, Zgodovinski časopis, Zwitterjev zbornik, Ljubljana 1965-1966, 273-274. 
Priloga 1:

Računska priloga-dopis Gašparja Maška Slovenskemu društvu za izvedbo druge besede 19. junija 1848 v Stanovskem gledališču. Dokument hrani Državni arhiv Slovenije.

Sentruementiecung

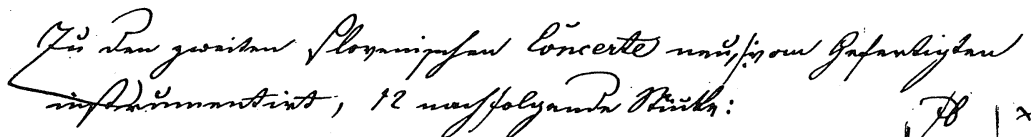

1. CPaven Pogran:

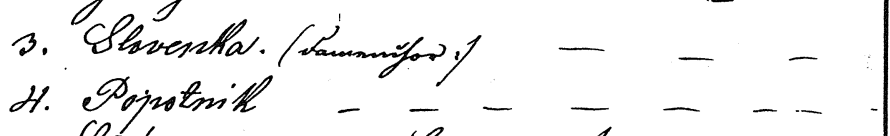

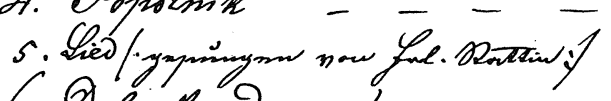

6. Dalensta zaravizal

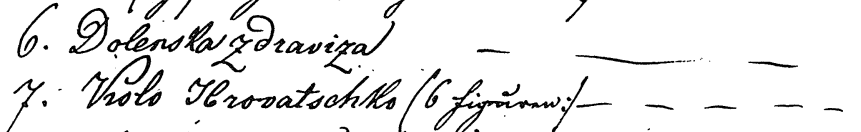

8. Hhio intro un shoje

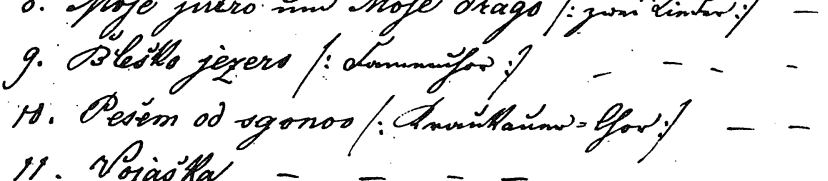

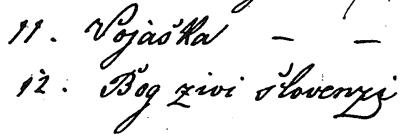

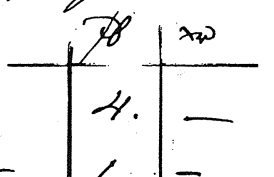

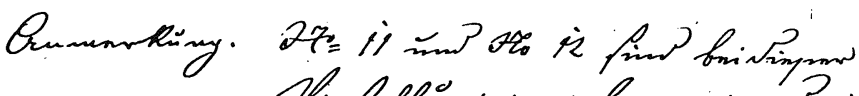

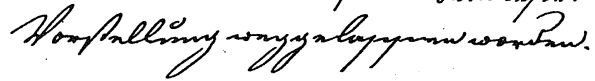

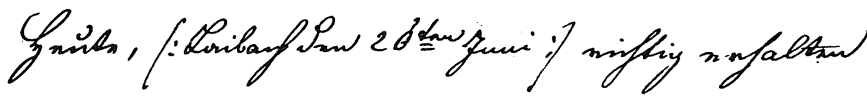

Id eft ig givion li.je.

e. Mn m ty

71 


\section{Priloga 2:}

Program besede $v$ goriški čitalnici 12. julija 1863. Vabilo hrani domoznanski oddelek Univerzitetne knjižnice v Mariboru med gradivom Slovanske čitalnice.

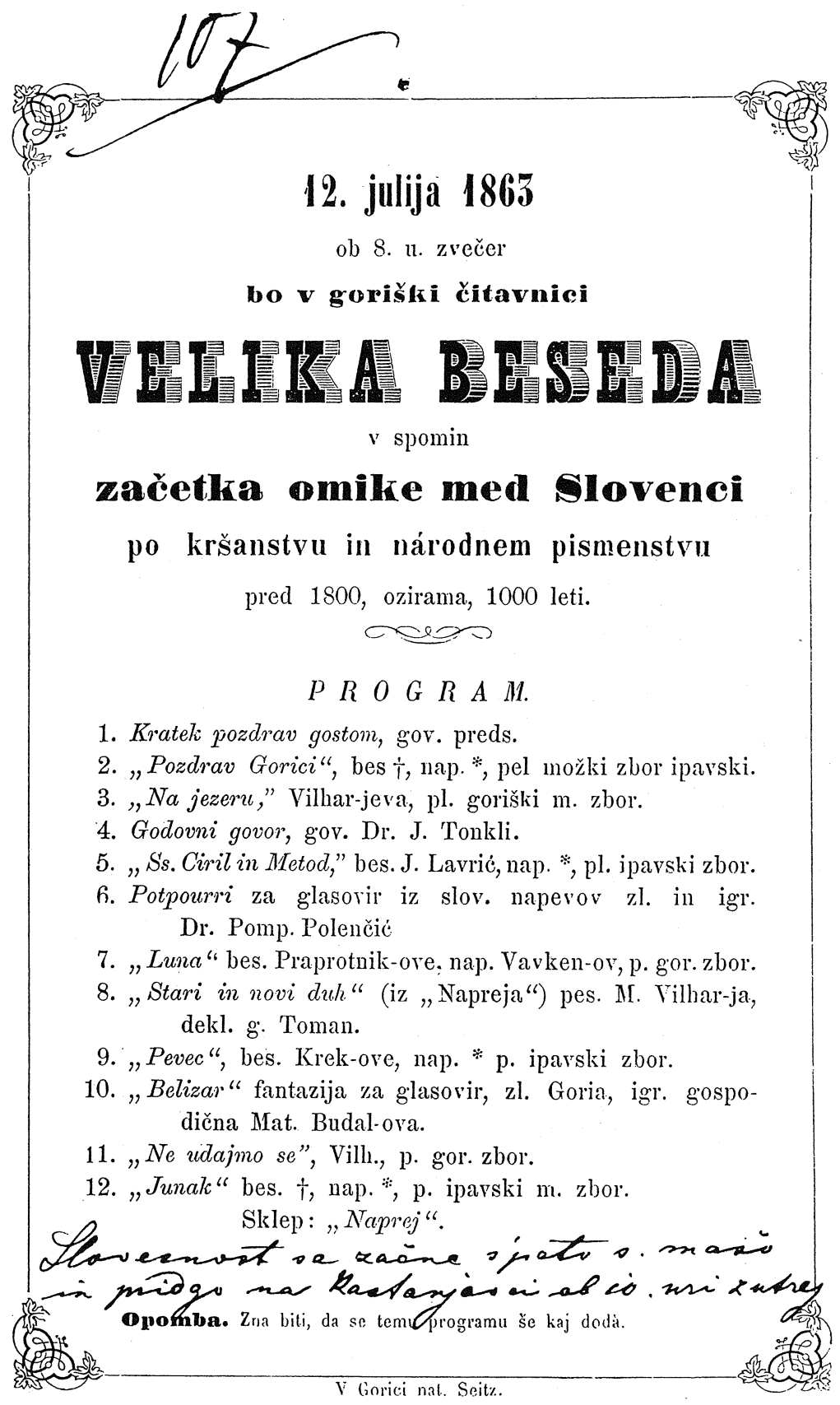




\section{SUMMARY}

The Slovene musical activity during the years 1848 and 1872, while belonging to the extreme fringes of the Central European musical history of the 19th century, nevertheless shows a quite specific kind of transition into the early "Romanticism ". Its marked characteristic is to be seen in the reduction and retardation of individual forms and of stylistic underdevelopment. This was the period of reading-rooms, caught in time when its culture was existentially determining the emerging "small« nations within the Habsburg monarchy, and was that foundation on which nationally awakening speeches, talks, recitations, playing and singing in the Slovene language were gradually forming the awareness of belonging to the Slovene nation. This goal was being served also by the "functionalized" music, unsophisticated lieder, songs for four parts, and utiliterian choruses. Their authors were spurred on by patriotism, which at the beginning produced rather modest results (Flajšman, Vilhar, partly Kamilo Mašek), while the composers of the second reading-room circle (Nedvěd, Gustav Ipavec, Jenko, Hajdrih) wholly or at least in part managed to wrest themselves from the bonds of diletantism, were more ambitious and musically already well informed.

The purpose of the present discussion is, on the one hand, to enrich factual information with new data, and, on the other, to penetrate below this upper level of note-making and to perceive the network of historical, social, and musical development which would make it possible to more sharply draw the line between actual and relative belatedness. Although from the compositional-technical and the stylistic viewpoint Slovenia was still for a few decades behind the current European musical developments, this period of twenty-five years proved for the Slovene circumstances extremely important. It represented the transition from diletantism to professionalism and shaped the foundations for the process of a gradual emergence of Slovene autochthonous, national music. 